\title{
Pollution Awareness among the Upper Primary Students of West Bengal
}

\author{
${ }^{1}$ Subhas Chandra Bhat, ${ }^{2}$ Kamal Krishna De $\&{ }^{3}$ Malay Kumar Sen \\ ${ }^{(1)}$ Asst Professor, Govt. College of Education, Banipur, 24 Parganas (North) \& Research Scholar, Department \\ of Education, Calcutta University \\ ${ }^{(2)}$ Former Principal, David Hare Training College, Kolkata-700019, \\ ${ }^{(3)}$ Associate Professor \& ex-Head of the Deptt. of Education, Calcutta University
}

\begin{abstract}
Tiblisi conference (1977) developed six objectives of Environmental Education in which 'environmental awareness' comes lowest in the hierarchy of cognitive development among the school children. This awareness acts as a motive force for the students to make their environment free from pollution and hazards. A study was conducted to find how far this awareness depends upon their sex and the pollution characteristics of the localities of their schools they read in. A sample of 1063 students completing their upper primary stage and comprising boys and girls hailed from schools situated in polluted and non polluting areas of West Bengal, India, was subjected to a test of awareness about 'environmental pollution'. It is found that pollution awareness of the students is almost independent of sex of the students and pollution characteristics in the neighbourhood of their schools but interaction of sex \& school locality have some significant impact on such awareness.
\end{abstract}

Key words: Environmental Pollution Awareness, Nonpolluting Zones, Lichens, Science Aptitude

\section{Introduction}

So far as the industrial revolution in the world started after sixteenth century, the gradual decay of environment was accelerated in all possible ways. Environmental Pollution broke out like a wild fire within only three hundred years. For meeting the ever-growing needs people put pressure on the environment. When the pressure exceeded the critical limit of carrying capacity of the environment to replenish itself, it created a serious problem of environmental degradation. Therefore, there is a social need to create 'awareness' about Environmental protection. While efforts are being made at the national and international level to protect our environment, it is also the responsibility of every citizen to use the environmental resources with more care and protect them from further degradation. To combat the effect of terrible lash of environmental decay in water, air and soil the whole human civilization became very careful. Ultimately this fighting could be started at ground root level through the education especially environmental education (EE). Environmental Education is an essential part of every pupils' learning. It helps to encourage awareness about the environment, leading to informed concern for active participation in resolving environmental problems (Sonowal, 2009).

Indian Education Commission (1964-66) suggested that school education has to offer EE and relate it to the life needs and aspirations of the people and the nation. Such education could generate awareness about environment and environmental degradation.

After the Stockholm Conference (1972), Belgrade Charter (1975) and Tbilisi conference on environmental education(1977), an all out preparation was made to introduce environmental education at all levels of general and technical education to encourage our young generation to fight the environmental pollution and to keep the earth safe. "In our daily activities and in our jobs, we have to make a concerted effort to educate ourselves, our children and our communities about the environmental consequences for our actions and to take responsibility for them." (Ronald Epstein, 1992)

If we have a close look at the objectives and curricula of elementary and secondary education in our states and also at national level (Chand,2007) we may notice that many aspects of 'environmental awareness' and more particularly of 'environmental pollution awareness' are already included in present science curriculum. So we have a scope to examine whether this content and practice of teaching science help to raise the desirable behaviour and attitude among the school children, which are congenial to environmental education.

Inter-governmental conference on environmental education in Tblisi, (the then) USSR (1977) formulated six objectives of which the lowest one is Awareness. A sizeable portion of students leave without proceeding to higher education. So the problem of environment should be presented before them in the form awareness of environment and its problems before their leaving school education. Their awareness about the set up of environment along with pollution of environment and consequent suffering of man make them cognizant about the behavior for prevention of pollution. Narayan (1981) mentioned a four-day international symposium 
(1971) in India which discussed, inter alia,(1) teaching, training and research in ecology \& (2) Environmental degradation and pollution. So, pollution got an important position in environmental education particularly in India since then.

Islam (2008) showed that the level of understanding awareness and participation of the respondents in the environmental friendly activities are low in Bangladesh. Along with many other recommendations, respondents in this country put stress on acquiring environmental information and tree plantation to overcome this situation.

Jackson (2010) criticized the existing school curricula stating that introduction of 'Environmental Problems' \& 'Discussion' into existing school curricula have caused incoherence due to lack of presence of science paradigm and solutions of environmental problems. It was also seen that majority of the teachers had moderate levels of environmental awareness. Female teachers had significantly higher levels of environmental awareness as compared to their male counterparts. Age-wise analysis also revealed that teachers with 31-50 years had higher levels of environmental awareness and lastly, teachers working in private schools were found to have significantly higher environmental awareness than teachers working in government schools

\section{Emergence of the Problem}

A major part of researches on environmental education at school level was done on Awareness \& Attitude of the students in primary schools. Some studies involving environmental pollution, awareness and school students are reported below.

Senapati \& Sahoo (2009) studied the knowledge of environment and environmental pollution -their understanding, causes and consequences in Odisha schools. Their study does not relate to test of pollution awareness of the students. Also the study did not consider the age, grade/class or locality of the schools of the students. Saxena (2009) made a study on the concepts of pollution of the primary grade students in general. Mohapatra(2009) studied the ideas of senior secondary students about global warming -one of the major types of environmental pollution of the day. Tehsin Fatima (2013) tested awareness of the public suffering due to industrial pollution. Sundaravalli (2012) Employed Environmental Pollution Awareness test to assess the level of environmental pollution awareness among student teachers with respect to their Gender, Age, Degree, Subject, Area of Residence etc. Karen Bickerstaff \& Gordon Walker ( 2001) interviewed a number of people over the environmental pollution to test their awareness about pollution. Astalin (2011) in his study has tried to find the environmental awareness among higher secondary students and some educational factors affecting it. It is observed from the above studies that:

(1) the studies have not include different stages of schooling, (2)the studies have not taken into account the awareness of the school students about pollution of environment, (3)the studies considered the awareness of the victims of pollution, sometimes the public in general or the school students of very lower or very higher classes. Eventually the upper primary stage has not been considered here, (4) the studies have not taken into account the awareness of non victims of pollution as against victims, (5) over and above; the studies on pollution awareness in West Bengal schools reported seem to be very small in number. So, a study has been designed to compare the pollution awareness of the students of the schools in polluting and non polluting zones of the districts of WB to address the following questions:

(1) Do the Boys and Girls of West Bengal Schools in the terminal upper primary stage differ in awareness related to environmental pollution? (2) Do the students of West Bengal schools located in polluted and non polluted zones differ in awareness related to environmental pollution?

\section{Definition Of Terms:}

Polluted and non-polluted zones (locations):

Polluting zone, in general, means the area having high density of population and polluting industries with low density of number of trees and plants. Moreover the absence of lichens and moss on trees or old buildings (Santra, 2001) has been taken as another indicator of such zones. Industrial areas of WB (e.g. Gangetic plateau of Howrah, North 24 Parganas, Hooghly) generally come under this zone.

Non-Polluted Zone is conspicuous by the presence of lichens and moss on trees or old buildings (particularly for air pollution)

Pollution awareness envisions:

- the increasing understanding of the environment pollution through education involving "knowledge or cognizance".

- awareness means to help people acquire sensitivity to the total environment and its allied problems and their implication.

- that the main goal of many schools today is to increase awareness because that is the only way to develop a more sustainable world. Accordingly, pollution awareness should begin with school education.

A student having pollution awareness has minimum working knowledge about: 
- environmental degradation

- factors causing environmental degradation

- concept of sustainable development, protection of environment etc.

The awareness about pollution generally concerns:

- $\quad$ sources of pollution,

- causes of pollution,

- prevention of pollution,

- removal of pollution \& development of environment.

The present study is limited to awareness about pollution of Air, Water and Soil only

\section{Objectives Of The Study:}

1. To compare the students of secondary schools (upper primary) sex-wise on the environmental pollution awareness

2. To compare the environmental pollution awareness of the students of secondary schools (upper primary) located in polluted and non-polluted zones of WB

\section{NULL HYPOTHESES:}

$\mathrm{H}_{01}$ : The boys and girls do not differ in mean scores in environmental pollution awareness

$\mathrm{H}_{02}$ : The students of the schools in polluted and non-polluted zones do not differ in mean scores on environmental pollution awareness

$\mathrm{H}_{03}$ : The boys and girls of schools in polluted zones do not differ in mean scores on environmental pollution awareness

$\mathrm{H}_{04}$ : The boys and girls of schools in non-polluted zones do not differ in mean scores on environmental pollution awareness

$\mathrm{H}_{05}$ : The boys of the schools in polluted \& non polluted zones do not differ in mean scores on environmental pollution awareness

$\mathrm{H}_{06}$ : The girls of the schools in polluted \& non-polluted zones do not differ in mean scores on environmental pollution awareness

\section{Methodology:}

Population of the study: Students passing VIII under WBBSE in Bengali medium schools are considered for this study. Class VIII is the terminal stage of upper primary stage up to which students mostly learn about environment through activity and observation, and up to this stage science and environment education are interwoven.

\section{Sample of the study:} Sampling:

As Polluted Zones (P zones) of West Bengal were identified as Kolkata, Howrah, South 24 Parganas, North 24 Parganas, Hooghly, East Midnapur and Burdwan of which three districts have been randomly chosen for the study. As non-polluted (NP) zones three districts of North Bengal have been randomly considered. The schools (Table-1) of the concerned districts were selected randomly with the following restrictions: Schools were selected from polluted \& non polluted zones, whose \% of passes in first division in Secondary Final examinations was between 50 to $75 \%$ for the last three years.

In all 1063 students were selected from these schools (Table-2). The distribution of schools and students of polluted and non-polluted zones is shown below.

Table-1 Zones vs. Schools

\begin{tabular}{|l|l|l|l|}
\hline Zones of Schools & $\begin{array}{l}\text { Boys' } \\
\text { schools }\end{array}$ & $\begin{array}{l}\text { Girls' } \\
\text { schools }\end{array}$ & $\begin{array}{l}\text { Total } \\
\text { No. } \\
\text { schools }\end{array}$ \\
\hline P zone of \\
\hline NPzone & 3 & 3 & 6 \\
\hline $\begin{array}{l}\text { Total No. of } \\
\text { schools }\end{array}$ & 6 & 3 & 6 \\
\hline
\end{tabular}

Table-2 Zones vs. Students

\begin{tabular}{|l|l|l|l|}
\hline Zones of Schools & No. of Boys & Girls & $\begin{array}{l}\text { Total No of } \\
\text { students }\end{array}$ \\
\hline P zone & 301 & 243 & 544 \\
\hline NPzone & 180 & 339 & 519 \\
\hline Total No.of Students & 481 & 582 & 1063 \\
\hline
\end{tabular}


Variables of study:

Independent variables: Two categorical variables: Sex and Zones (Locations) of the schools

Dependent variables: Environmental Pollution Awareness

Tools: 1. Test developed by Bhat, De \& Sen (2012) on Awareness on Environmental Pollution containing dimensions is shown as follows:

Table-3 Dimensions of Awareness Test (as per WBBSE, Curriculum, Class-VIII, 2005)

\begin{tabular}{|l|l|l|l|l|}
\hline \multirow{2}{*}{$\begin{array}{l}\text { Dimensions of } \\
\text { Pollution Awareness }\end{array}$} & \multicolumn{2}{|l|}{ No. of items in each dimension } & $\begin{array}{l}\text { Total } \\
\text { Items }\end{array}$ \\
\cline { 2 - 5 } & Air Pollution & $\begin{array}{l}\text { Water } \\
\text { Pollution }\end{array}$ & Soil Pollution \\
\hline Concerns of Pollution & & & & 7 \\
\hline Sources of pollution & 2 & 3 & 2 & 10 \\
\hline Causes of pollution & 3 & 4 & 3 & 12 \\
\hline Prevention of pollution & 4 & 4 & 4 & 12 \\
\hline Removal of pollution & 4 & 4 & 4 & 41 \\
\hline Total & 13 & 15 & 13 & \\
\hline
\end{tabular}

2. Discrimination Index (D.I.) .Items having DI value below 11(i.e 20\%) were cancelled.

3. Facility Index- F.I. of retained 41 items vary from $40 \%-84 \%$

On the three dimensions of the test, 41 items were originally prepared. The content validity test was checked by experts on environmental science and education. The reliability of the test was found by test -retest method where reliability coefficient is $r=0.536(p<0.05)$ for $\mathrm{df}=132$. The internal consistency of the items were found by Bunch-total correlation. Marking Scheme used for scoring was 1 for right answer \& 0 for wrong or incomplete answer.

Table-4 Bunch Total Correlation $(\mathrm{df}=148)$

\begin{tabular}{|l|l|l|l|}
\hline Dimensions & Air $\left(\mathrm{T}_{1}\right)$ & Water $\left(\mathrm{T}_{2}\right)$ & Soil $_{2}\left(\mathrm{~T}_{3}\right)$ \\
\hline Total$(\mathrm{T})$ & $\mathrm{r}_{1}=0.824$ & $\mathrm{r}_{2}=0.847$ & $\mathrm{r}_{3}=0.807$ \\
\hline & $\mathrm{P}<0.01$ & $\mathrm{P}<0.01$ & $\mathrm{P}<0.01$ \\
\hline
\end{tabular}

\section{Presentation of Data:}

Table-5 Frequency distribution of scores:

\begin{tabular}{|l|l|l|l|l|l|l|l|l|l|}
\hline Intervals & 1 & 2 & 3 & 4 & 5 & 6 & 7 & 8 & 9 \\
\hline $\begin{array}{l}\text { Midpoints of } \\
\text { scores }\end{array}$ & 02 & 7 & 12 & 17 & 22 & 27 & 32 & 37 & 42 \\
\hline Freq & 0 & 012 & 046 & 127 & 302 & 312 & 211 & 053 & 0 \\
\hline
\end{tabular}

Fig:1 Frequency Polygon representing the frequency distribution of the Awareness scores of the students in table-4 is shown below:

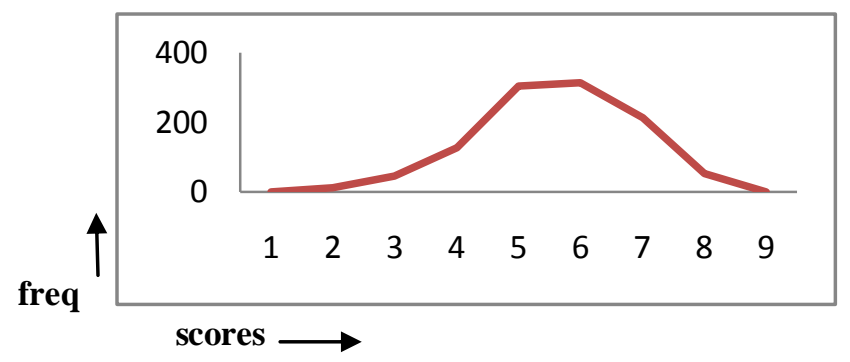

The fig -1 shows that the single curve representing the frequency distribution of sores is almost normal.

Table-5 Descriptive Statistics of pollution Awareness Scores

\begin{tabular}{|l|l|l|l|l|l|l|l|l|l|}
\hline Statistics & Etot & Enp & Ep & Eb & Eg & Enpb & Enpg & Epb & Epg \\
\hline $\mathrm{N}$ & 1063 & 519 & 544 & 481 & 582 & 180 & 339 & 301 & 243 \\
Mean & 28.0113 & 28.1272 & 27.9007 & 28.5572 & 27.5601 & 27.6222 & 28.3953 & 29.1163 & 26.3951 \\
Std. Error of Mean & .18600 & .27414 & .25254 & .26200 & .26049 & .38967 & .36471 & .34431 & .34840 \\
Std. Deviation & 6.06430 & 6.24525 & 5.89013 & 5.74614 & 6.28434 & 5.22794 & 6.71504 & 5.97353 & 5.43104 \\
Variance & 36.776 & 39.003 & 34.694 & 33.018 & 39.493 & 27.331 & 45.092 & 35.683 & 29.496 \\
Skewness & -.320 & -.247 & -.409 & -.367 & -.259 & -.376 & -.259 & -.440 & -.620 \\
Kurtosis & -.178 & -.411 & .084 & -.186 & -.197 & -.230 & -.567 & -.145 & .477 \\
\hline
\end{tabular}


Abbreviations: Etot- Environment Pollution awaernes(EPA) scores for total sample, Enp EPA scores of the students of non polluted zones Ep-EPA scores of the students of polluted zones, Enpb-EPA scores of the boys of non-polluted zone, Enpg-EPA scores of girls of non polluted zones, Eb-EPA scores of boys etc.

\section{Analysis:}

To find the main effects of 'sex' and 'location of schools' and their interaction ANOVA was designed for 50 scores selected randomly from each of the cells : Boys, Girls, Polluted and Non polluted locations of schools.

Table- 6 ANOVA of $2 \times 2$ factorial designs of Sex and Location Tests of Between-Subjects Effects

Dependent Variable: Environmental Pollution Awareness Scores(EPAS)

\begin{tabular}{|c|c|c|c|c|c|}
\hline Source & $\begin{array}{l}\text { Type III Sum of } \\
\text { Squares }\end{array}$ & df & Mean Square & $\mathrm{F}$ & Sig. \\
\hline $\operatorname{sex}$ & 52.020 & 1 & 52.020 & 1.550 & $0.215(\mathrm{p}>0.05)$ \\
\hline Location of schools & 32.000 & 1 & 32.000 & .954 & $0.330(\mathrm{p}>0.05)$ \\
\hline sex $*$ location & 169.280 & 1 & 169.280 & 5.045 & $0.026(\mathrm{p}<0.05)$ \\
\hline Error & 6576.200 & 196 & 33.552 & & \\
\hline
\end{tabular}

\section{Interpretation of Table 6 :}

Difference of Boys and Girls in EPAS (Environmental Pollution Awareness Scores) is not significant ( $p>0.05)$. Difference of EPAS of students of the schools in Polluted and Non polluted zones (locations) is not significant $(p>0.05)$. Hence t-tests are not necessary in this respect. Interaction between sex \& locations of the schools is significant $(\mathrm{p}<0.05)$ indicating that though sex and locality of the schools have no individual impact on awareness, their joint effect has significant impact on pollution awareness of the students. Descriptive statistics shows that girls in the non polluted zones and boys in the polluted zone schools are better in Environmental Pollution Awareness Scores (EPAS).

\section{Findings:}

(1) The boys and girls do not differ in mean scores on (EPAS). Hence null hypothesis $\mathrm{H}_{01}$ is retained.

(2) The students of polluted and non-polluted zones do not differ in mean scores on

( EPAS).Hence null hypothesis $\mathrm{H}_{02}$ is retained.

(3) The boys and girls of polluted zones do not differ in mean scores in ( EPAS). Hence null hypothesis $\mathrm{H}_{03}$ is retained.

(4) The boys and girls of non-polluted zones do not differ in mean scores on ( EPAS). Hence null hypothesis $\mathrm{H}_{04}$ is retained.

(5) The boys of polluted \& non polluted zones do not differ in mean scores in (EPAS). Hence null hypothesis $\mathrm{H}_{05}$ is retained.

(6) The girls of polluted \& non-polluted zones do not differ in mean scores in (EPAS). Hence null hypothesis $\mathrm{H}_{06}$ is retained.

(7)Girls obtained higher scores in non polluted zone schools in comparison to boys but lower scores in the other zones as evident from the interaction effects in ANOVA (Table-6) and descriptive statistics (Table-5).

\section{Limitations of the study:}

1. Lifestyle of the students is very important in such studies which bring the students to the reality of the environment but it was beyond the scope of the present study.

2. There is no single indicator which can detect all types of major environmental pollution in a locality. As such moss and lichens were considered which identifies air pollution only.

\section{Discussion:}

1. The mean Awareness scores of the students were low in comparison to Maximum Scores fixed for the test.

2 The mean scores of the students of different sex and zones remained very close to one another.

3. According to NCF (2005) "Group activities, discussions with peers and teachers, surveys, organization of data and their display through exhibitions, etc, in the schools and the neighborhood should be important components of pedagogy" for Environmental studies. But in practice this type of pedagogy is hardly followed in the schools. There is no systematic arrangement in the schools to promote the observation of the students about the problems of their environment. This might be one of the reasons for no difference among the students of different categories of students. 
Shet (2003) observed that while most of the Geography textbooks did discuss the importance of the atmosphere, hydrosphere and lithosphere in detail, and focused on the greenhouse effect, ozone depletion etc, there is little effort to interlink environmental concepts and real life experiences.

However some NGOs under the guidance of NCSTC (National Council of Science and Technology Communication), Delhi conduct NCSC (National Children's Science Congress) every year in different parts of India. In doing so the NGOs undertake different scientific activities done by the students on different parameters of environments -cleanliness, air soil, water, nutrition, energy conservation, atmosphere ,pollution, contamination etc. Some self supported organization like All India Science Teachers' Association also undertakes activities in this line. But all students can't be covered in this process. So no difference could be found among them as regards environmental pollution awareness.

4. Eco club of the schools conducted some participatory activities in the past but they are not in existence now. Sharma (2004) in his article clearly stated that curriculum of EE should be framed with a lot of activities so that students can learn everything by their own thinking. Teacher specially should be trained very carefully and intensively through field trips, excursions, nature study etc.

5. The investigators conducted a simultaneous study on the same sample(of the present study) for Science related Pollution Concepts(SPC) and Science Aptitude (SA) of the students. They found that Environmental Pollution Awareness(EPA) is highly correlated with Pollution Related Scientific Concepts( $\mathrm{r}=0.5629, \mathrm{df}=1061$, $\mathrm{p}<.05)$ and the Scientific Aptitude of the students( $\mathrm{r}=0.5972, \mathrm{df}=1061, \mathrm{p}<0.05)$.

Narayan \& Suhanae (2010) stated neither scientific aptitude nor its components significantly influence environmental practices of secondary school students. Scientific aptitude had significant influence on limiting use of poly products. They also observed that significant influence of scientific attitude on environmental practitioners among the students. To them scientific attitude has direct positive effect on the environmental practices of the students. Components of scientific attitude like curiosity, open mindedness were significantly influencing environmental practices and sensitivity of secondary school students. Contribution of scientific attitude was evident on three components of environmental practices, namely, conservation of nature, control of noise pollution and limiting use of poly products. Therefore to resolve the environmental problems should not only depend on science and technology and the law, but also make an appeal to environmental ethics

\section{Conclusion:}

(1) Environmental pollution awareness of the school students may not be always positively related to gender of the students and the pollution level of the locality of the schools they study in. However this awareness is dependent on the joint effect of sex and the locality of the schools in which they read.

(2) The pollution awareness of the students does not always depend on the non cognitive group characteristics of the students (like sex, locality and so on) .

(3) Environmental awareness of the students on the other hand is positively and significantly correlated to individual/personal characteristics of the students ( like attitude, aptitude, sensitivity etc)

(4) Age along with social \& political circumstances (UN, 2004) of the students sometimes influences pollution awareness of the students.

(5) Students might not be aware of the pollution, if the scientific background of the nature of pollution is not clear to them (Mahapatra,2009)

\section{Reference}

[1]. Anita Gupta 'Traffic Pollution' in School Science, Vol.-XXXIX, No-4 , Dec-2001, Pp13-17

[2]. Astalin, P. K. (2011) A Study Of Environmental Awareness Among Higher

[3]. Secondary Students And Some Educational Factors Affecting It in Zenith

[4]. International Journal of Multidisciplinary Research Vol.1 Issue 7 November www.zenithresearch.org.in

[5]. Bickerstaff, K \&, Walker, G.(2011) 'Public understandings of air pollution: the\&localization of environmental risk' in Global Environmental Change 11 (2001) Division of Geography, Stawordshire University, College Road, Stoke on Trent, ST4 2DE, UK Pp133-145 http://www.des.ucdavis.edu/faculty/handy/ESP178/Understanding_of_air_pollution.pdf

[6]. Chand, J.(2007) .Environmental Education. Anshah Publishing House; Delhi

[7]. Das, R.(2006):Development Vs Sustainability in Senapati, Tilottama \& Sahoo, R.K.(2009):Environmental Education and Pollution control. Mittal Publications, New Delhi(India) p-29

[8]. Eugine,T.(2004):Environmental Economics. Vrinda Publications(P)Ltd,Mayur Vihar ,Delhi-91

[9]. Islam, N. (2008) 'Public Awareness About Environmental Issues: Perspective Bangladesh' in http://www.cdrb.org/journal2008//2/3.pdf dl 23.09.14

[10]. Jackson, M. G. "Effective Environmental Education needs 'New' Science', in Indian Educational Review, Vol-37, No-2, 2010;Pp20-36

[11]. Kothari, D.S. (1964-66) 'Indian Education Commission' . Deptt. of Education,Govt. of India, N. Delhi

[12]. Laskhmi Narayan, U. and Anjali Suhanae 'Contribution of Scientific Aptitude and Scientific Attitude to Develop Environmentally Scientific Practices' in Indian Educational Review, Vol. 4, No1, January, 2010 Pp72-85

[13]. Mahapatra, A. K. 'Students' perception of the global Warming' in Journal of Indian Education Vol.XXXV No1 May 2009Pp3545)

[14]. Narayan, D.S.(1981) : 'Environment Education :a Profile' in Impact of the Development of Science and Technology on Environment(Eds: Sharma\& Sharma); $68^{\text {th }}$ session of Indian Science Congress Association, Pp 119-31

DOI: $10.9790 / 0837-191250107 \quad$ www.iosrjournals.org $\quad 6$ Page


[15]. NCERT(1988): National Curriculum Framework.N. Delhi

[16]. Paikray, R.K.\& S.N. Mahapatra(2006) in Senapati, Tilottama \& Sahoo

[17]. Ronald Epstein(1999) 'Pollution and the Environment: Some Radically New Ancient Views' Vajra Bodhi Sea: A Monthly Journal of Orthodox Buddhism. Pt. 1, v. 30 (Dec. 1999), pp. 36, 12

[18]. Roy, R. \& Paira, Anjana (2008):Environental Awareness Among Students. in Environmental Education(Ed. R.Roy), Shipra Publications, Shankarpur ,Delhi-92.

[19]. Sahoo,R.K.(2009):Environmental Education and Pollution control. Mittal Publications, New Delhi(India) p-29

[20]. Saxena , P.( 2009): Comprehending The Concept Of Environmental Pollution Among Primary Grade Students.... An Analytical Study.http://www.ssmrae.com/admin/images /2eea73282f0f5798ae26cb 14196ed7fb.pdf/25.5.14

[21]. Senapati, Tilottama\& Sahoo,R.K.(2009):Environmental Education and Pollution control. Mittal Publications, New Delhi(India)

[22]. Shankar Narayan,D.( 1981). "Environment Education: a profile" in Impact of the Development of Science and Technology on Environment(Ed. Sharma \&Sharma) Indian Science Congress Association,1981 Pp 119-131

[23]. Sharma, R.C. 'Implication of Environmental Education in Teacher Education' in Journal of Indian Education, Vol-XXX, No-1, May,2004 Pp5-11

[24]. Sharma, V.Muralidhara(2006): Enviromental Pollutions:Ancient Solutions in the light of Sanskrit Literature, March 2026,vol44,No.12

[25]. Shilpa Shet (2003) 'Info Change News \& Features', Pune-based journalist August, 2003[http://infochangeindia.org]

[26]. Simioni, D. (Compiler): ‘Air Pollution \& Citizen Awareness' U..N.(2004), p-42

[27]. Sonowal, C.J. (2009) 'Environmental Education in Schools:The Indian Scenario' in Journal of Human Ecology,Tata Institute of Social Sciences,Mumbai,Vol.28, No.1,Pp15-36[www.krepublishers.co - Retieved on12.10.2012

[28]. Sundaravalli(2012) Student teachers awareness on Environmental Pollution in International Journal of Teacher Educational Research (IJTER) Vol.1 No.4 December, 2012 ISSN: 2319,p-8

[29]. (http://www.latest-science-articles.com / Retrieved on 03-03-2010) 